\title{
DYEING OF COTTON FABRIC WITH NATURAL DYE FROM Cudrania javanensis USING SOKA (Ixora javanica) LEAVES EXTRACT AS BIO-MORDANT
}

\author{
Pencelupan Kain Katun dengan Pewarna Alam dari Cudrania javanensis dengan
}

\section{Ekstrak Daun Soka (Ixora javanica) sebagai Bio Mordant}

Cici Darsih', Dwi Wiji Lestari ${ }^{2}$, Diah Pratiwi ${ }^{1}$, A. Wheni Indrianingsih', Vita Taufika Rosyida ${ }^{1}$, Wuri Apriyana ${ }^{1}$, Khoirun Nisa ${ }^{1}$, Septi Nur Hayati ${ }^{1}$, Sri Handayani ${ }^{1}$, dan Martha Purnami Wulanjati $^{1}$

${ }^{1}$ Research Unit for Natural Products Technology,Indonesian Institute of Sciences, Gading, Playen,

Gunungkidul, Yogyakarta, 55581, Indonesia

${ }^{2}$ Centre for Handicraft and Batik, Jl. Kusumanegara No. 7, Yogyakarta, 55166, Indonesia

\section{Author's correspondence}

Email : cici001@lipi.go.id

\author{
Paper Recieved : 06 August 2019 \\ Revisioned : 08 August 2019 \\ Aproved : : 15 November 2019
}

Keywords : bio-mordant, color strength, Cudrania javanensis, fastness properties, Ixora javanica, natural dye, soka leaves extract

Kata kunci: bio mordant, kekuatan warna, Cudrania javanensis, Daya tahan luntur, Ixora javanica, pewarnaan alami, ekstrak daun soka

\begin{abstract}
This study was aimed to evaluate the potential application of soka (Ixora javanica) leaves extract as bio-mordant in dyeing process on cotton fabrics using Cudrania javanenis extract. The post mordant process was carried out in this study and Alum $\left(\mathrm{KAl}\left(\mathrm{SO}_{4}\right)_{2} \bullet 12 \mathrm{H}_{2} \mathrm{O}\right)$ solution was used as comparison mordant with the concentration of 0.5 and $1 \% \mathrm{~b} / \mathrm{v}$. Characteristic of dyed cotton fabrics then was evaluated using Fourier-Transform Infrared (F-TIR) Spectroscopy and Al content on soka leaves was determined using Inductively Coupled Plasma (ICP). Soka leaves comprise $11.9 \%(\mathrm{w} / \mathrm{w})$ of aluminium. The optimal color strength was achieved when the cotton was dyed with C. javanensis using $0.5 \%$ alum. The fastness properties of dyed cotton against light and washing at $40^{\circ} \mathrm{C}$ exhibited poor values as of 1-2 and 1, respectively. The dry and wet rubbing fastness of dyed cotton using soka leaves extract mordant was better than that using alum in fastness properties. The results showed that generally the fastness properties of dyed cotton with $C$. javanensis using bio-mordant soka leaves extract was similar to alum. This is suggested that soka leaves extract can be used as alternative mordant in dyeing process
\end{abstract}

\begin{abstract}
ABSTRAK
Penelitian ini bertujuan untuk mengevaluasi potensi aplikasi ekstrak daun soka (Ixora javanica) sebagai bio-mordan dalam proses pewarnaan kain katun menggunakan ekstrak Tegeran (Cudrania javanenis). Dalam penelitian ini, digunakan mordan akhir larutan tawas/alum (KAl (SO4) ${ }_{2} \cdot 12 \mathrm{H}_{2} \mathrm{O}$ ) sebagai pembanding mordan ekstrak daun soka dengan konsentrasi 0,5 dan 1\% b/v. Karakteristik kain katun yang diwarnai kemudian dievaluasi menggunakan Spektroskopi Fourier-Transform Infrared (F-TIR) dan kandungan Al pada daun soka ditentukan menggunakan Inductively Coupled Plasma (ICP). Daun Soka terdiri dari 11,9\% (b/b) aluminium. Kekuatan warna optimal dicapai ketika kain katun dicelup dengan C.javanensis menggunakan 0,5\% tawas. Sifat ketahanan luntur warna terhadap cahaya dan pencucian pada $40{ }^{\circ} \mathrm{C}$ masing-masing menunjukkan nilai yang buruk yaitu bernilai 1-2 dan 1. Ketahanan luntur
\end{abstract}


gosok kering dan basah kain yang dimordan menggunakan ekstrak daun soka lebih baik dibandingkan menggunakan tawas. Hasil penelitian menunjukkan bahwa secara umum sifat tahan luntur kain katun yang diwarnai dengan C. javanensis menggunakan bio-mordan ekstrak daun soka memiliki kemiripan dengan tawas. Hal ini menunjukkan bahwa ekstrak daun soka dapat digunakan sebagai alternatif mordan dalam proses pewarnaan.

\section{INTRODUCTION}

Batik is a traditional fabric from Indonesia and it was recognized as one of the Indonesian's cultural heritages by the United Nations Educational Scientific and Cultural Organization (UNESCO) in 2009. Some of Indonesian textile small medium scale enterprises generally used natural dyes such as Merbau wood (Intsia bijuga), tegeran wood (Cudraina javanensis), tingi bark (Ceriops candolleanaarn), coconut coir (Cocos nucifera), jalawe, mahoni bark (Swietenia mahagoni), secang wood (Caesalpinia sappan L.) and indigo (indigofera) in the dyeing process of batik. The use of natural dyes for coloration of batik has been growing because they were considered to be more environmentallyfriendly, non-carsinogenic, non-toxic, and biodegradable (Aliet al 2009; Bechtold et al. 2003).

Several reports have discussed on the use of natural dyes for dyeing process with various mordants. The results showed that mordant gave a variety of colors on fabrics and increased the color strength value and fastness properties of the dyed fabrics (Atika et al. 2017; Ohama et al. 2014; Haji 2010; Haque 2013). In Indonesia, mordanting process usually used metallic mordant such as $\mathrm{CaCO}_{3}, \mathrm{FeSO}_{4}$, and $\mathrm{KAI}(\mathrm{SO} 4)_{2} \cdot 12 \mathrm{H}_{2} \mathrm{O}$. Another mordant which can be used as bio-mordant is soka leaves.
Soka belongs to Rubiaceae family and found in tropical South East Asia. This leaves suggested contain aluminum. Dycotyledons have ability to accumulate of alumunium and it is correlated with primitive character mainly characteristic of woody and tropical plants. The families of dycotyledones which are alumunium-accumulators such as Aniosophylleacea, Hydrangeaceae, Melastomataceae, Rubiaceae, Theaceae, Symplocaceae, and Vochysiaceae (Chenery and Sporne, 1976) In this research, C.javanensis wood was used as natural dyes for batik and soka leaves extract was used as bio-mordant. C. javanensis belongs to Moraceae family and grow in Asia, Australia, and Polynesia (Hutchinson, 1967). Previous, research reported that $C$. javanensis can be used as single color on batik using metallic mordant (Atika et al. 2017). This research aims to evaluate $C$. javanensis wood extract as single color on the dyeing process of batik using bio-mordant soka leaves extract. $C$. javanensis plant contains constituents of alkaloids, carbohydrates, fats and oils, flavonoids, glycosides, gums, phenols, proteins, saponins, steroids and tannins (Swargiary et al. 2013, Kalita et al. 2009, Sarmah et al. 2010).

\section{METHODOLOGY}

\section{Materials}


C. javanensis (tegeran wood, local name) and the cotton fabric were purchased from local markets in Yogyakarta, Indonesia.

Soka leaves were obtained from Bulaksumur, Sleman, Yogyakarta and used as bio-mordant. Soka leaves were dried in an oven at temperature $60^{\circ} \mathrm{C}$ for 2 hours. Furthermore the dried leaves were grounded to become a powder and its $\mathrm{Al}$ content was analyzed by inductively coupled plasma (ICP)in Center for Environmental Health Engineering and Disease Control (B/BTKLPP) Yogyakarta. $\mathrm{KAl}\left(\mathrm{SO}_{4}\right)_{2} \bullet 12 \mathrm{H}_{2} \mathrm{O}$ was used as metallic mordant.

\section{Equipments}

The experiment instruments were used in this study: bucket, wood stirrer, oven (Memmert UF 110), grinder (Philips HR2116).

The instruments were used for analysis: Color reader (Konica Minolta Color Reader CR-20 and UV-PC spectrophotometer (Shimadzu UV-2401-PC), and F-TIR spectrophotometer (Shimadzu IRPrestige21).

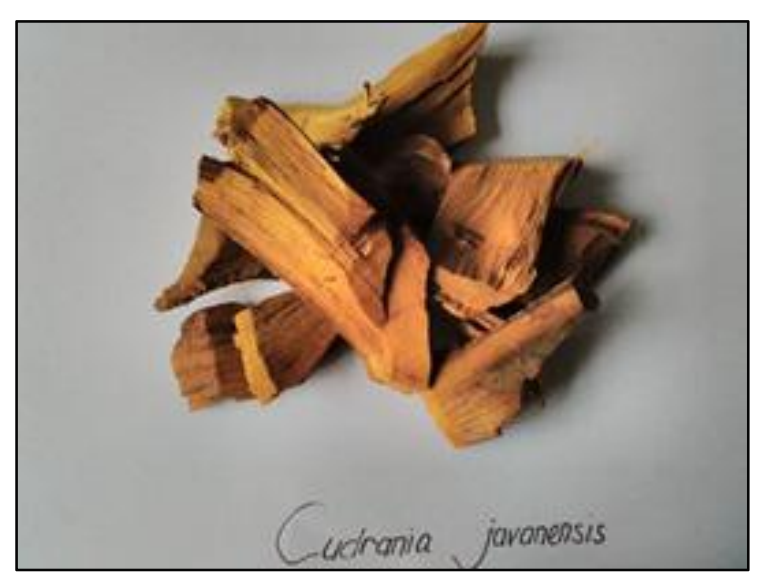

Figure 1. C. javanensis wood

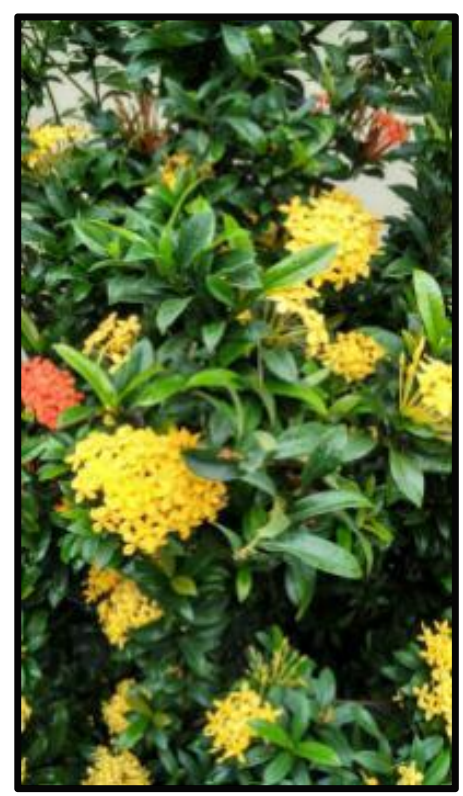

Figure 2. I. javanica leaves

\section{Pretreatment of Fabric}

The cotton fabrics were pre-treated with detergent and Turkish Red Oil (TRO) (5:1 for $2 \mathrm{~m}$ of fabric) and then they were rinsed with tap water and dried at room temperature.

\section{Colorant extraction}

The $C$. javanensis was extracted using water in the weight ratio of 1:5 and boiled at temperature $\sim 100{ }^{\circ} \mathrm{C}$ for 1 hour. Furthermore the extract $C$. javanensis was cooled for 1 hour before dyeing process.

\section{Dyeing of Cotton Fabrics}

Dyeing of cotton fabric using $C$. javanensis aqueous extract was carried out for 15 minutes at room temperature. Furthermore, the fabrics were dried at room temperature. This step was held to five times.

\section{Mordanting Method}

Post-mordant process was used in this study. Post mordant was carried out after 
dyeing process. The fabrics were soaked in $0.5 \%$ soka leaves extract $(A), 1 \%$ soka leaves extract (B), $0.5 \% \mathrm{KAI}\left(\mathrm{SO}_{4}\right)_{2} \cdot 12 \mathrm{H}_{2} \mathrm{O}$ solution (C), and $1 \% \mathrm{KAl}\left(\mathrm{SO}_{4}\right)_{2} \cdot 12 \mathrm{H}_{2} \mathrm{O}$ solution (D) for 5 minute. Then, they were washed thoroughly in a tap water and air dried at room temperature.

\section{Characterization of Dyed Fabrics}

Functional groups and vibrations between functional group on dyed fabrics were characterized using Fourier-Transform Infrared (F-TIR) Spectroscopy. FTIR analysis of dyed fabrics was performed on a wavelength from $500 \mathrm{~cm}^{-1}$ to $4000 \mathrm{~cm}^{-1}$.

\section{Color Measurement}

Color measurement was analyzed with a UV-2401-PC spectrophotometer. K/S expressed the relative color strength of dyed fabrics and evaluated by the light reflectance technique using the KulbekaMunk equation.

$$
\frac{K}{S}=(1-R)^{2} / 2 R
$$

$R$ is the decimal fraction of the reflectance of dyed fabric. K/S was determined by one step dying process [5].

The CIELab values were ascertained with alum and bio-mordant soka leaves extract (Table 1). Results were expressed in $L^{*}, a^{*}$, and $b^{*}$, with $L^{*}$ (how light or dark the sample is), ranging from black (0) to white (100), $a^{*}$ ranging from green $(-60)$ to red $(+60)$ and $b^{*}$ ranging from $(-60)$ to yellow $(+60)$. These values were determined using Color Reader CR-20.

\section{Fastness Properties Test}

Fastness properties of dyed cotton fabrics were tested for washing, rubbing, and light properties according to SNI ISO 105-C 06:2010, SNI ISO 105-X12:2012, and SNI ISO 105-B01:2010.

\section{Statistical Analysis}

CIE $L^{*} a^{*} b^{*}$ values of dyed cotton were conducted in triplicate $(n=3)$. Statistical analysis was performed with SPSS 16.0 for one-way analysis of variance (ANOVA) followed by post hoc Duncan's test. Differences at $p<0.05$ were considered to be significant.

\section{RESULTS AND DISCUSSION}

\section{Results}

The function groups as part of a compound were evaluated by FTIR spectroscopy. Figure $\mathbf{3}$ shows the IRspectra of dyed cotton with $C$. javanensis. The FTIR spectra of dyed cotton were evaluated at the frequency of $4000-500 \mathrm{~cm}^{-}$ 1 .

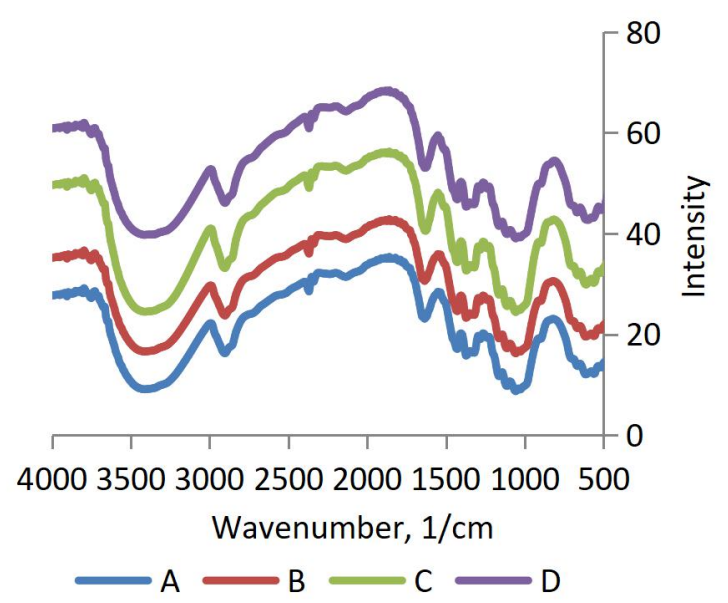

Figure 3. Spectra IR of dyed cotton with $C$. javanensis with various mordants.

The dyed cotton was evaluated for color strength and CIE Lab values of fabrics as shown in Table 1. 
Table 1. $K / S$ and CIE $L^{*} a^{*} b^{*}$ values of dyed

\begin{tabular}{ccccc}
\hline $\begin{array}{c}\text { Expe- } \\
\text { riment }\end{array}$ & $\boldsymbol{L}^{*}$ & $\boldsymbol{a}^{*}$ & $\boldsymbol{b}^{*}$ & $\boldsymbol{K} / \boldsymbol{S}$ \\
\hline A & $67.80^{\mathrm{d}}$ & $10.23^{\mathrm{a}}$ & $53.67^{\mathrm{a}}$ & 0.05 \\
& \pm 0.0 & \pm 0.06 & \pm 0.12 & \\
& & & & \\
B & $67.33^{\mathrm{c}}$ & $10.30^{\mathrm{a}}$ & $53.63^{\mathrm{a}}$ & 0.04 \\
& \pm 0.06 & \pm 0.10 & \pm 0.12 & \\
& & & & \\
C & $62.10^{\mathrm{a}}$ & $12.27^{\mathrm{c}}$ & $61.13^{\mathrm{b}}$ & 0.10 \\
& \pm 0.26 & \pm 0.12 & \pm 0.64 & \\
& & & & \\
D & $63.07^{\mathrm{b}}$ & $11.80^{\mathrm{b}}$ & $60.93^{\mathrm{b}}$ & 0.07 \\
& \pm 0.06 & \pm 0.00 & \pm 0.06 & \\
\hline
\end{tabular}

cotton with a post-mordanting method The different letter superscript in the table shows a significant difference at $p<0.05$

Table 2 shows the fastness properties of dyed cotton with various mordants.

Table 2. Fastness properties of dyed cotton fabrics

\begin{tabular}{|c|c|c|c|c|c|}
\hline \multirow{2}{*}{ No } & \multirow{2}{*}{$\begin{array}{l}\text { Fastness } \\
\text { properties }\end{array}$} & \multicolumn{4}{|c|}{ Results } \\
\hline & & A & B & C & $\overline{\mathbf{D}}$ \\
\hline \multirow[t]{2}{*}{1} & Washing at $40^{\circ} \mathrm{C}$ & & & & \\
\hline & Change in color & $1-2$ & $1-2$ & 2 & 2 \\
\hline 2 & Light fastness & 1 & 1 & 1 & 1 \\
\hline \multirow[t]{3}{*}{3} & Rubbing & & & & \\
\hline & Dry rubbing & $4-5$ & 4 & 4 & 4 \\
\hline & Wet rubbing & $3-4$ & $3-4$ & 2 & 3 \\
\hline
\end{tabular}

\section{Discussion}

The chemical bonds and molecular structure of material was identified using FTIR spectroscopy. The existence of specific chemical bond in any material is indicated from the presence of peak at a specific wave number. The broad absorption band, which appears in the range $3600-3200 \mathrm{~cm}^{-1}$ is related to collective absorption by $\mathrm{O}-\mathrm{H}$ stretching in polymer. This absorption indicated the bonding of natural dye extract with cotton fiber. A strong absorption peak appears at $1627-1635 \mathrm{~cm}^{-1}$ for dyed cottons is indication carbonyl $(C=O)$ groups. The results showed that four dyed cottons exhibited same functional groups and vibrating between functional groups. It is suggested that both using alum and soka leaves extract have same binding between $C$. javanensis extract on cotton.

A statistical analysis of the results using ANOVA $(p<0.05)$ suggest that the mean $L^{*}$ of dyed cottons were significantly different (Table 1). The $L^{*}$ values related to the lightness of cotton. In this study, the mean values of $L^{*}$ ranged from $62.10-67.80$. The mean of $L^{*}$ dyed cotton with $0.5 \%$ soka leaves extract higher than dyed cotton with $1 \%$ soka leaves extract, $0.5 \%$ alum, and $1 \%$ alum as mordant. The $b^{*}$ values are related to yellowish color of dyed cottons. The mean values of $b^{*}$ of dyed cotton with $0.5 \%$ and $1 \%$ soka leaves extract were not significant different, but significantly different to dyed cotton with $0.5 \%$ and $1 \%$ alum mordants.

The mean values of $b^{*}$ ranged from 10.2312.27. The $a^{*}$ value correlated with the reddish color of the dyed cotton. The mean values of $a^{*}, b^{*}$, and visual analysis showed that dying using $C$. javanensis with alum mordant gave yellow reddish color on cotton and bright yellow when using soka leaves extract as mordant. Postmordanting process with different mordant give effect 
on fabrics color (Haque 2013; Prayitno et al. 2014). The optimal strength color was achieved when the cotton was dyed with $C$. javanensis using $0.5 \%$ alum as mordant. The yellow color of the $C$. javanensis wood extract was suggested from flavonoid compounds in this plant (Septhum et al. 2007).

The colorfastness properties of cotton fabrics were shown in Table 2 . The gray scale within the range 1-5 was used as the color change on fabrics, where one is poor, and five is outstanding. The results showed that washing cotton fabrics at $40^{\circ} \mathrm{C}$ showed poor values in change color with range value of 1-2. Dyed cotton fabric both mordanted using alum and soka leaves extract exhibited very poor properties toward light fastness with a score of 1 . The colorfastness score to dry and wet rubbing on cotton with bio-mordant soka leaves extract better than cotton with alum mordant. The poor values of fastness properties of dyed cotton with $C$. javanensis because this extract belong to natural dyes, which need mordant in its dyeing process. Mordanting process in this natural dyes group can be done with several techniques; pre-mordanting, simultaneous mordanting, and post mordanting. Mordant act as chemical bridge between natural dyes and fibres of fabric. They improve the take-up quality of the fabrics and help increase color and fastness properties of dyed fabrics (Gratha,2014). The poor affinity of $C$. javanensis extract on cotton fabrics was suggested that pre-mordanting process did not carried out in this research. Based on the results, it can be suggested that generally soka leaves extract can be used as an alternative mordant in dyeing process. In this research, soka leaves extract was used as bio-mordant because it contains a substantial amount of alumunium. Soka leaves comprise $11.9 \%(\mathrm{w} / \mathrm{w})$ of alumunium. Alumunium content has been suggested to provide chelation to the dye molecules. It can be seen in Figure 4.
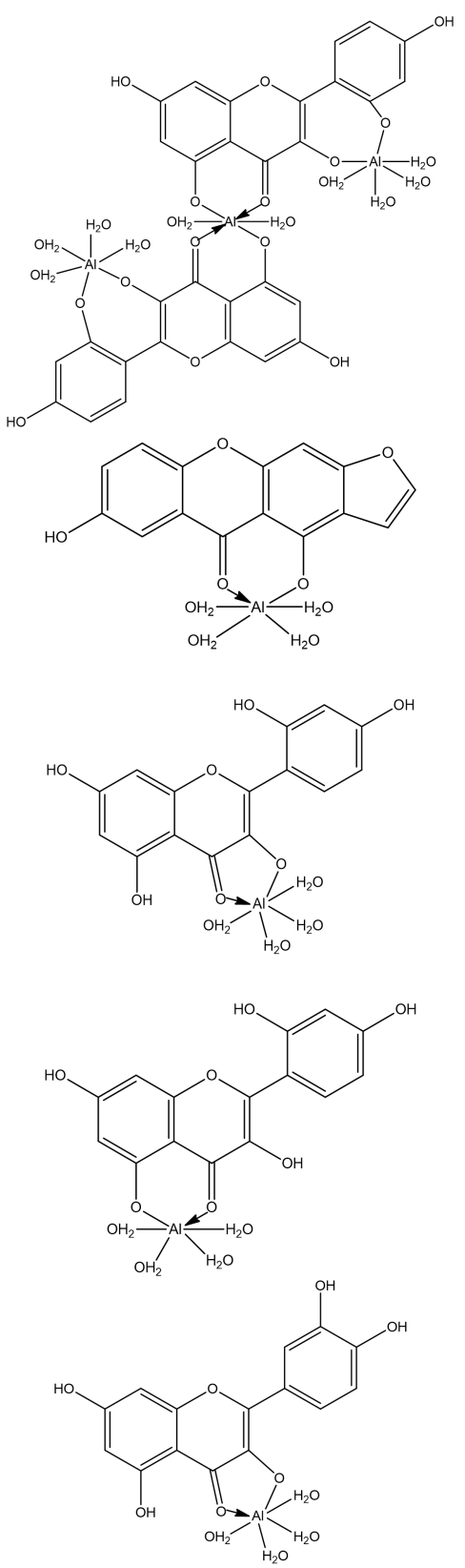

Figure 4 The proposed structures of chelation between $\mathrm{Al}$ content on mordant with compounds isolated from $C$. javanensis (Septhum et al. 2007, Knapp et al. 1971) 


\section{CONCLUSIONS AND SUGGESTIONS}

\section{Conclusion}

Color strength of dyed cotton with $C$. javanensis using bio-mordant soka leaves extract lower than using alum mordant, while the fastness properties toward washing at $40^{\circ} \mathrm{C}$, light, and dry rubbing were similar with mordant alum. It means that soka leaves extract suggested that can be used as alternative mordant in dying process.

\section{Suggestion}

Soka leaves extract can be used as mordant for others natural dye on dyeing process.

\section{AUTHORS CONTRIBUTION}

Main contributors : Cici Darsih, Dwi Wiji Lestari, and Diah Pratiwi

Member contributors : A. Wheni Indrianingsih, Vita Taufika Rosyida, Wuri Apriyana, Khoirun Nisa, Septi Nur Hayati, Sri Handayani, Martha Purnami Wulanjati

\section{ACKNOWLEDGEMENT}

This project was fully supported by Indonesian Institute of Sciences, the Government of Indonesia. The research was conducted by Research Divison for Natural Material Technology.

\section{REFERENCES}

Ali, S., Hussain, T., \& Nawaz,R. (2009) Optimization of alkaline extraction of natural dye from Henna leaves and its dyeing on cotton by exhaust method.Journal of Cleaner Production, 17(1),6166.

Bechtold, T., Turcanu, A., Ganglberger, E., \&Geissler, S. (2003) Natural dyes in modern textile dyehouses - how to combine experiences of two centuries to meet the demands of the future? Journal of Cleaner Production, 11(5),499509.

Atika, V., \& Salma, I.R.(2017). Kualitas Pewarnaan Kayu Tegeran (Cudrania javanensis) pada Batik.Dinamika Kerajinan dan Batik.34 (1),11-18

Chenery, E.M., and Sporne K.R., (1976) A Note on the Evolutionary Status of AlumuniumAccumulators among Dicotyledons. New Phytologist. 76, 551-554

Gratha, Benny. (2012). Panduan Mudah Belajar Membatik. Jakarta: Demedia

Haji, A.(2010). Functional Dyeing of Wool with Natural Dye Extracted from Berberis vulgaris Wood and Rumex Hymenosepolus Roos as Biomordant. Iranian Journal Chemistry \& Chemical Engineering. 29 (3), 55-60

Haque, M.A., Khan, G. M. A., Razzaque, S., M. A., Khatun, K., Chakraborty, A. K., \& Alam, M.S.(2013). Extraction of Rubiadin Dye from Swietenia mahagoni and Its Dyeing Characteristics Onto Silk Fabric Using Metallic Mordants.Indian Journal of Fibre \& Textile Research, 38,280-284.

Hutchinson, J. (1967). The Genera of Flowering Plants (vol. 2). England:Clarendon Press, Oxford, 166

Knapp, J.E., \& Schiff, Jr., P.L. (1971). Isolation and Identification of Constituents from Cudrania javanensis, Journal of Phrarmaceutical Science. 60 (11), 1729-1730

Kalita, M., Sarmah, G.K., Bora, M.N., Das, B., Jibon, K. (2009). Molecular and crystal structure of an isoflavanoid $\quad 5, \quad 7, \quad 4$ 'trihydroxy-6,3'diprenylisoflavone from Cudrania javanensis. Indian Journal of Chemistry. 48B, 1324-1328

Prayitno, R.E., Wijayana, S., dan Diyah, B.S.(2014). Pengaruh Bahan Fiksasi terhadap Ketahanan Luntur dan Intensitas Warna Kain Mori Batik Hasil Pewarnaan Daun Alpukat Persea Americana Mill.). Fakultas Teknologi Pertanian, Universitas Brawijaya

Ohama, P., \& Tumpat, N. (2014) Textile Dye from Sappan Tree (Caesalpinia sappan Linn.) Extract. International Journal of Chemical, Molecular, Nuclear, Materials and Metallurgical Engineering. 432-434

Septhum C., Rattanaphani, V., \& Rattanaphani, S. (2007). UV-Vis Spectrometric Study of Natural Dyes with Alum as A Mordant.Journal of Science and Technology. 14 (1), 91-97

Swargiary, A., \& Ronghang, B. (2013). Screening of Phytochemical Constituents, Antioxidant and Antibacterial Properties of Methanol Bark Extracts of Maclura cochichinensis (Lour) Corner.International Journal of Pharma \& Bioscience. 4(4). 449-459 
IKh Dinamika Kerajinan dan Batik: Majalah Ilmiah. Vol. 36 No. 2, Desember 2019, Hal 105-112

Sarmah, G.K., \& Sarma, R.K. (2010). Isolation and Identification of Biological Activite Isoflavanoid from Cudrania javanensis, Journal of Phytology. 2(5), 47-49 